\title{
THEOLOGY AND SCIENCE IN DIALOGUE. SIGNPOSTS AND PERSPECTIVES
}

\author{
Assoc. Prof. PhD Ion Marian CROITORU, \\ Faculty of Orthodox Theology and Education Sciences, \\ Valahia University of Târgoviște, \\ ROMANIA \\ E-mail: ioncroitoru@yahoo.fr; im.croitoru@yahoo.gr
}

\begin{abstract}
One can note that science tends to turn man into a master of the external and material, yet at the cost of turning him, on the level of his inner and spiritual life, into a slave of instincts altered by sin. All these, without a moral norm, become a power of destruction for man and represent issues addressed not just by bioethics, where the opinion of 'theologians' is consulted as well, but especially by the Church and by the Orthodoxy. The pressure of events imposes the issue of the recognition or, according to some, reformulation of the bases of ethics. Yet, this ethics ought to be constrained to a revision founded neither just on the progress of science, whose truths are partial, nor on the principles of rationalist or positivist philosophy, which try to convince man that he is no different from all the other living beings and needs to be treated in the same way as them, but on the reality of the religious fact, and, moreover, on the evidence of God's Revelation and, implicitly, of Christian anthropology, based on the fact that man bears God's image, not the image of man himself, as a society attempting to exclude God in an absolute manner wills to herald. According to the Holy Church Fathers, one must pursue not a concordism or discordism of theology and science but their dialogue from a theological and, implicitly, eschatological perspective. The first, namely theology, relies on the knowledge of God and the receiving of the supernatural gifts by the action of the divine uncreated energies, by means of man's collaboration with God, which supposes man's commitment to advance on the steps of the spiritual life: cleansing, illumination, deification. The second, namely science, relies on knowing the surrounding world and on putting to use the natural gifts, also given by God to man, and by which man investigates the reasons of things, recognising God's power, wisdom and presence. Therefore, to theology correspond the spiritual knowledge and wisdom from Above, while to science correspond lay knowledge and the wisdom from the outside or from below. At the basis of these acts is the difference between Uncreated and created, between Uncreated and created energies. Thus, the Holy Fathers distinguish between observations from natural sciences and their consecrated philosophical interpretations, yet which they signal and condemn if these interpretations do not converge with the theological perspective, in other words, with the divine Revelation, because the texts of the Holy Scriptures are inspired by God and what is included in them is situated at a different depth of knowledge than what belongs to human knowledge.
\end{abstract}

Keywords: God; Jesus Christ, theology; science; faith, reason; mind, heart; Big Bang, evolutionism, theism, deism; 
I (Introduction). Science and faith [in God] have often been considered antinomic ${ }^{1}$, although reason, which science relies on, and faith, to which we return below, are part of man's being, by what theologians call man's ontological given, which he received by the fact of his creation by God. For believers in God, accepting the fact of creation brings a global vision on the existence, but also the perception of man as mystery, having an aim in creation: to get from the state in God's image to the state of God's likeness, involving in this process the entire creation for its transfiguration by the divine uncreated grace.

This vision is cultivated in the Orthodox Church and exemplified by the Saints' presence, so that in the Orthodox theology we talk not about a conflict between faith and science, but rather about their dialogue, based on several considerations, of which we indicate just a few in this study, as many as we can present in the time allotted for a conference in the framework of an International Symposium.

Both religious fact, recognized ever more by scientists, and science have a common denominator, which is faith. It is part, as we mentioned above, of man's ontological given and founds his spiritual and intellectual convictions. Any scientist founds the approach of an experiment or his intellectual convictions on his faith ${ }^{2}$ referred to the respective domain or to the value system he has in view, when trying to transform a hypothesis into theory, accepted or not, later on, by the academic and scientific environment to which he belongs. This faith common to any man is called, in patristic language, rational faith, not because it would have to do only with man's reason or intellect, since it is also feeling, but because it works with the reason and the intellect concerning the man's thinking, convictions and acts, being also called faith of acceptance. Regarding, however, the religious fact, moreover, the Orthodoxy, this faith does not straighten man, namely does not save him; it only leads him to his quest of God. When man looks for God and gets to live the God glorified in the Holy Trinity, he requests in prayer, as a gift, the inner faith or the faith of the heart, fruit of the living of God's uncreated-grace's work in his heart, by the prayer of the mind. In this way, man feels the work of the mind in his heart, so that he thinks not just with his reason and intellect in the brain, but also with his mind in his heart, by which he sees unseen things ${ }^{3}$.

One might complain that such an approach is theoretical, although it expresses the experiences of the Saints, by whose steps the Church walks in history, yet in response to such

\footnotetext{
* For the first Romanian version of this study, see "Teologia și știința în dialog. Repere și perspective", in Facultatea de Teologie Ortodoxă și Științele Educației, Misiune, Spiritualitate, Cultură, Simpozion Internațional „Teologie și persoană. Abordare teologică, pedagogică și bioetică”, 13-14 noiembrie, 2014, Editura Valahia University Press, Târgoviște, 2015, pp. 209-236.

${ }^{1}$ Jean-Pierre Lonchamp, Știință și credință, translation from French by Magda Stavinschi, afterword by Fr. Doru Costache, Col. Noua reprezentare a lumii, XXI: Eonul dogmatic, București, 2003, p. 9 (henceforth: Lonchamp, Știință și credință); Albert Einstein, Cum văd eu lumea. O antologie, texts selected by M. Flonta, I. Pârvu, translation by M. Flonta, I. Pârvu, D. Stoianovici, notes by M. Flonta, Editura Humanitas, București, $2005^{3}$, pp. 282-290 (henceforth: Einstein, Cum văd eu lumea); see also Basarab Nicolescu, Magda Stavinschi (editors), Știință și religie. Antagonism sau complementaritate?, Editura XXI: Eonul dogmatic, București, 2002; John F. Haught, Știință și religie de la conflict la dialog, translation from English by Magda Stavinschi, Doina Ionescu, Editura XXI: Eonul dogmatic, București, 2002; University of Craiova, Centre for Dialogue between Sciences and Theology, Simpozionul Național "Știință și Teologie - componente complementare ale educației", first edition, Editura Universitaria, Craiova, 2005; ibidem, second edition, Editura Universitaria, Craiova, 2006.

2 In fact, contemporary epistemology shows very well that science relies on beliefs, from where also the approach from scientific beliefs to experimental proof (Lonchamp, Știință și credință, pp. 10, 68-69).

${ }^{3}$ About the two belief types, see Părintele Ioan Romanidis, Teologia patristică, translation from Greek, notes, bibliographic completions and afterword by Ion Marian Croitoru, Editura Bibliotheca, Târgoviște, 2012, pp. 67 68 (henceforth: Romanidis, Teologia patristică).
} 
an objection one can bring even the position of those sincerely and objectively interested in the issue of the relation of faith, implicitly theology, to science. According to this position, the first difference between faith and science concerns their headquarters: faith starts from the heart, science starts from the brain; faith relies on feeling, science on reasoning ${ }^{4}$. Consequently, the conflict between faith and science is deceptive, starting from the mistake usually made, namely, judging faith by science and the other way round. While science analyses, disassembles, and then builds, synthesizes, in exchange, faith looks from the start at life, with all its aspects, as a block; it always appears complete and not in pieces ${ }^{5}$. Reasoning and the living or experiencing of the uncreated-grace-filled work of God, by the axis of the spiritual life, cleansing-illumination-deification, are two ways, differing as method, yet leading, nonetheless, both to the truth that all the world thirsts for ${ }^{6}$. From our Saviour Jesus Christ's words to Saint Thomas the Apostle, when He invited him to touch His rib and the signs of the nails in His hands, because you have seen Me, you have believed. Blessed are those who have not seen and yet believed (John 20: 29), it results that there is a faith based on senses (seeing, touching etc.) and another, superior faith, of divine essence, which does not depend on material signs ${ }^{7}$.

This expression is specific of the one living and making known such a difference between the two faiths, mentioned above, yet impressive is that this remark comes precisely from a lay teacher, aware of the Middle-Ages Roman-Catholic Church abuses in matters of faith, which turned a part of the human soul to the field of science and of reason, to Luther's Reformation, forerunner of the great [French] Revolution (1789), meant to overturn the tyranny of false faith. Thus, true science is in harmony only with true faith, and, based on this principle, faith and science, although different as method, are unique as aim, rely on each other: faith keeps our spiritual composition, gives us our tranquillity, peace; while science by investigations, check-ups and trials, protects us from superstitions, invents new means on the material realm, makes them available to faith ${ }^{8}$. In other words, science spreads out the forces of the soul to investigate, to find, and faith gathers them again, to lift ${ }^{9}$, since 'Science' draws close to 'the Truth' step by step, by small, measured and remeasured steps, while 'Faith', the great, from one bond draws close to the same 'Truth', emanating from God ${ }^{10}$.

The Romanian intellectuals' conviction, at the beginning of the $20^{\text {th }}$ century, was that the respective century will be an aware collaboration of faith with science for the moral and

\footnotetext{
${ }^{4}$ Anton V. Andreiu (teacher at Vasile Alecsandri High School of Galați), Credință și știință. Conferință ținută la Societatea Clerului "Solidaritatea", Secția Covurlui, în ziua de 24 Februarie 1929, Galați, 1929, p. 1 (henceforth: Andreiu, Credință și știință).

${ }^{5}$ Andreiu, Faith and science, p. 2.

${ }^{6}$ Andreiu, Faith and science, p. 2.

${ }^{7}$ Andreiu, Faith and science, p. 5.

${ }^{8}$ Andreiu, Faith and science, p. 6.

${ }^{9}$ Andreiu, Faith and science, p. 7.

${ }^{10}$ Andreiu, Faith and science, p. 9. Faith permits, therefore, the 'leap' where 'demonstration' can go no further. It requires a participation, an acceptance of the divine initiative of dialogue, it is, in essence, an experience leading to what is, at the same time, knowledge and beyond knowledge, if we refer to a getaway from the conceptual framework of the knowledge of the material world. We can see it as pneumatic charismata giving birth to theological reflection, being explicitly the result of a synergy of the manifestation of the created and of the uncreated, a cooperation of man's natural power with God's divine grace. Only so can man advance theologically, helped by God's grace, beyond the discursive intelligence and its categories, because the latter functions only comparing realities of this world, wherefrom the limits of its definitions [Răzvan Andrei Ionescu (Pr.), Teologie Ortodoxă și Știință: Conflict, Indiferență, Integrare sau Dialog? Care să fie atitudinea noastră față de știință?., Editura Doxologia, Iași, 2015, p. 183 (henceforth: Ionescu, Teologie Ortodoxă și Știință)].
} 
material good of mankind ${ }^{11}$, including a touch of nationalism ${ }^{12}$. Yet, the respective conviction includes one more nuance. Of evolutionist conception, yet recognizing the Orthodox Church's merits compared to the Roman-Catholic Church's approach, along the centuries (Inquisition, forced unification to Rome of the Romanians of Transylvania etc.), Victor Babeș (1854-1926), invoking Pasteur's experience, formulates the principle that faith should never claim the right to prevent the progress of science, and science should never intrude in the sphere of individual and consoling faith ${ }^{13}$. However, this principle calls for interpretations, because science, if it forsakes the dimension of faith in God and the respect to His creation, if it fails to recognize man's unique value in the universe, but also the aim for which man has been created, gets to promote theories and practices detrimental both to man and to the environment.

II. Despite its achievements, science shows, as well, its limits. On the one hand, it has proved powerless to answer fundamental questions concerning the sense of the universe and of man (why was the universe created? who is man? where does he come from? where is he going to? what happens after death?), and, on the other hand, one can note, especially, its incapacity to found an ethics. The one that will answer the problem of meaning is not science ${ }^{14}$, but faith in God. Science kindles admiration and enthusiasm, but also a great number of concerns (for instance, nuclear threat, radioactive wastes, decoding of the genetic information contained in the human chromosomes, control over hereditary diseases, prenatal diagnosis generalization, 'abnormal' embryos' elimination, the situation of 'supranumerary' embryos etc. $)^{15}$, which become more numerous, paradoxically, as man's scientific knowledge increases. Consequently, man knows how to clone people and, therefore, does it. Man knows how to use people as 'spare' organs for other people, and, for this reason, he does it; he does it because this seems to be an exigence of his freedom. Man knows how to make atomic bombs and makes them, being ready, in principle, also to use them ${ }^{16}$. On the one hand, if science turned man into the master of the exterior, material world, on the other hand, it is still science that turned man, on the level of the inner and spiritual life, into a slave of instincts altered by $\sin ^{17}$. Yet, all these, without a moral norm, become a power of destruction for $\operatorname{man}^{18}$ and represent problems in which competent is not just bioethics, in

\footnotetext{
${ }^{11}$ Andreiu, Faith and science, p. 7.

12 We, the Romanians, situated geographically between the scientific, analyst West, and the empiricist, synthesist East, even mystical sometimes, are the nation meant to be among the first to prove that in man's soul can live together a clear faith with a serious science, assuring a harmonious progress (Andreiu, Faith and science, p. 7).

${ }^{13}$ Victor Babeș, Credința și știința. Ședință publică a Ateneului Român dela 4 iunie 1924, București, 1924, p. 7.

${ }^{14}$ Lonchamp, Știință şi credință, pp. 10, 145, 159; Einstein, Cum văd eu lumea, p. 66; see also Francis S. Collins, The Language of God: a Scientist Presents Evidence for Belief, Free Press, New York, London, Toronto, Sydney, 2007, p. 6 [henceforth: Collins, The Language of God; for the translation into Romanian see idem, Limbajul lui Dumnezeu. Un om de știință aduce dovezi în sprijinul credinței, translation from English by Silvia Palade, Editura Curtea Veche, București, 2009, p. 12 (henceforth: Collins, Limbajul lui Dumnezeu)].

${ }^{15}$ Lonchamp, Știință și credință, pp. 150-151. The most striking practical effect of science consists, according to Einstein, in the fact that it allows inventing things that enrich life, although, at the same time, they complicate it (Einstein, Cum văd eu lumea, p. 270).

16 Joseph Ratzinger, Europa în criza culturilor, translation by Delia Marga, introduction by Andrei Marga, Editura Biblioteca Apostrof, Cluj-Napoca, 2008, pp. 50-51 (henceforth: Ratzinger, Europa)

${ }^{17}$ Traian-Alexandru Miu, Globalizare și Ortodoxie. Provocări și perspective, Editura Universitară, București, 2015, p. 100.

${ }^{18}$ Ratzinger, Europa, p. 50; Einstein, Cum văd eu lumea, p. 270.
} 
which theologians are ask to give their opinion, too, but especially the Church and the Orthodoxy.

The most worrying phenomenon represents what technoscience is called, namely pure sciences with their applications, whose functioning and applicability tend to escape any control. Technoscience or applied science ${ }^{19}$ give man extraordinary powers, allowing for undisputable progresses, yet, simultaneously bringing also an extremely dangerous capacity of destruction ${ }^{20}$. Moreover, the means provided by technoscience are spectacular, but have led as well to the formation of an awareness of the incompleteness of sciences and of their insufficiency to provide answers that the human conscience is waiting for ${ }^{21}$.

Consequently, an ethical organization is needed, so that the power acquired by man, by the progress of technoscience, may not become a curse on himself ${ }^{22}$. The moral or ethical force has not grown concomitantly to the development of science; on the contrary, it has diminished, because the technological mentality limits morality to the subjective sphere. Observing the lack of balance between technical possibilities and moral energy ${ }^{23}$, lucid scientists long for a deep ethical reflection, but in a world where all the values have been relativized, or even contested, the very idea of establishing ethical or juridical barriers is judged sometimes as anachronical and an attempted attack against freedom ${ }^{24}$. However, the pressure of events imposes the problem of recognizing or, according to some, reformulating the bases of ethics. Yet, this ethics must not be constrained to a revision founded only on the progress of science, whose truths are partial ${ }^{25}$, nor on the principles of rationalist or positivist philosophy, which are trying to convince man that he is not unlike all the other living beings and needs to be treated like them ${ }^{26}$, but on the reality of the religious fact, and all the more on the evidence of God's Revelation and, implicitly, of Christian anthropology ${ }^{27}$, based on the fact that man carries God's image, and not that of man himself, as it is intended to be prefigured in a society excluding God absolutely ${ }^{28}$.

III. The apparent conflict between faith and science is related, according to some Christian thinkers and scientists, to the visions of exegesis on the Holy Scripture. It ought to be signalled that Galileo Galilei (1564-1642) was constrained to express himself in this domain, too, out of necessity, to fight the reproach made to the Roman-Catholic prelate Nicolaus Copernicus/Copernic (1473-1543) of having entered in contradiction with some biblical texts (Joshua 10: 12-13; Job 9: 7; Ps. 103: 5), supporting heliocentrism. In his Letter to Christine de Lorraine, of 1615 , Galileo, in fact a strong believer to the end ${ }^{29}$, quoted the

\footnotetext{
${ }^{19}$ Einstein, Cum văd eu lumea, p. 270.

${ }^{20}$ Lonchamp, Știință și credință, p. 153; Einstein, Cum văd eu lumea, p. 270.

${ }^{21}$ Doru Costache (Pr.), "De la conflict și confuzie la complementaritate și dialog. Jean-Pierre Lonchamp, istoria științei și raporturile dintre știință și credință”, in Lonchamp, Știință și credință, p. 164; see also Roger Penrose, Incertitudinile rațiunii (Umbrele minții). In căutarea unei teorii științifice a cunoașterii, Ed. Tehnică, București, 1999; Jürgen Habermas, Joseph Ratzinger, Dialectica secularizării. Despre rațiune și religie, translation by Delia Marga, introduction by Andrei Marga, Editura Biblioteca Apostrof, Cluj-Napoca, 2005.

${ }^{22}$ Lonchamp, Știință şi credință, p. 153; Ratzinger, Europa, p. 41.

${ }^{23}$ Ratzinger, Europa, p. 42.

${ }^{24}$ Lonchamp, Știință și credință, p. 154.

${ }^{25}$ Lonchamp, Știință și credință, p. 158.

${ }^{26}$ Ratzinger, Europa, p. 51.

${ }^{27}$ Albert Einstein admitted that the highest principles for our aspirations and judgements are given to us in the Jewish-Christian religious tradition (Einstein, Cum văd eu lumea, p. 284).

${ }^{28}$ Ratzinger, Europa, pp. 46, 48, 52.

${ }^{29}$ Collins, The Language of God, p.158 (Collins, Limbajul lui Dumnezeu, p. 168).
} 
famous sentence of the Romano-Catholic cardinal Caesar Baronius (1538-1607) that in the Bible, the Holy Spirit's intent is to teach us how to go to heaven and not how the sky is ${ }^{30}$. For Galileo, the literal interpretation does not apply to any biblical text, so that the truths of the Scripture and the truths of science are not opposable ${ }^{31}$.

Actually, in history, there have been debates between literalists and non-literalists on the interpretation of the Holy Scripture and, especially, of the first book of the Old Testament, Genesis. In support of the mediation of the scientific visions by the theological ones, a fragment of Blessed Augustine's thinking is invoked, who, aware of the risk of turning the biblical texts into scientific treaties and referring explicitly to the Book of Genesis, affirmed: In matters that are so obscure and far beyond our vision, we find in Holy Scripture passages which can be interpreted in very different ways without prejudice to the faith we have received. In such cases, we should not rush in headlong and so firmly take our stand on one side that, if further progress in the search for truth justly undermines this position, we too fall with it ${ }^{32}$.

But, in this point, one more mention ought to be made, in harmony with patristic living. On the one hand, the Holy Fathers recommend no unjustified use of hermeneutics or literal exegesis, specific of the Catechetic School of Antioch, or allegorical (symbolical) interpretation, characteristic of the Catechetic School of Alexandria ${ }^{33}$. On the other hand, exegesis is not just simple human openness in front of the text; it is, in essence, openness to the One Who inspired the holy author and Who is God Himself. For this reason, exegetes should be coparticipants in 'spiritual battles', namely cleansed from passions, and, so, God, by His grace, offers the true reading key for the revealed text, which puts in communion God, the holy author and the exegete ${ }^{34}$. Saint Gregory Palamas affirms clearly: in the universe there is only one truth ${ }^{35}$ and the Holy Spirit's grace is the only key of the Holy Scripture ${ }^{36}$.

Therefore, any apparent conflict can be overcome, and, often, scientific theories were no longer upholdable following the research undertaken, and equally attitudes of the Western Churches have been rectified, in the course of time. For instance, Luther, followed by Melanchthon and Calvin, reacted vehemently against Copernicus ${ }^{37}$. After Galileo's condemnation, in 1633, and, implicitly, of Copernicus' system, the Roman-Catholic Church will admit only in 1822 that the Earth's mobility does not contradict the Scripture ${ }^{38}$.

\footnotetext{
${ }^{30}$ Lonchamp, Știință și credință, p. 77. The same Letter also comprises an answer of Galileo, which can be any believer scientist's logo: I do not feel obliged to believe that the same God Who has endowed us with sense, reason and intellect has intended us to forgo their use [Collins, The Language of God, p. 158 (Collins, Limbajul lui Dumnezeu, p. 168)].

${ }^{31}$ Lonchamp, Știință și credință, p. 78. Ignorance of Galileo's research and erroneous interpretation of the patristic tradition are met even among today's Orthodox clerics, who consider Galileo as a heretic, and other scholars as kabbalists, see, for instance, Dan Bădulescu (Pr.), Conflict intre "legile” științei și minunile credinței, Editura Agaton, Făgăraș, 2008, pp. 42, 45.

${ }^{32}$ Saint Augustin, The Literal Meaning of Genesis, transl. by John Hammond Taylor, Ed. Newmann Press, New York, 1982, 1: 41, apud Collins, The Language of God, p. 83 (Collins, Limbajul lui Dumnezeu, p. 92).

${ }^{33}$ Ionescu, Teologie Ortodoxă și Știință, p. 175.

${ }^{34}$ Ionescu, Teologie Ortodoxă și Știință, p. 179.

${ }^{35}$ Sfântul Grigorie Palama, Triade II, 1, 5, apud Ionescu, Teologie Ortodoxă și Știință, p. 212.

${ }^{36}$ Sfântul Grigorie Palama, Triade II, 1, 6, apud Ionescu, Teologie Ortodoxă și Știință, p. 214.

${ }^{37}$ Lonchamp, Știință și credință, pp. 64-65.

${ }^{38}$ Lonchamp, Știință și credință, p. 79. The Second Council of Vatican (1963) will express allusive regrets to Galileo's case, and Pope John Paul II (1978-2005) admits the suffering caused to Galileo by the Church people and organisms (10 November 1979) (Lonchamp, Știință și credință, p. 79). It ought to be mentioned that on 31 October 1992, the same pope expressed his regret for the way Galileo's case was treated, and emitted a
} 
Polemics were been, however, between some scientists, as well. Let us remember, for example, the polemic of Isaac Newton (1643-1727) and Gottfried Wilhelm (von) Leibniz (1646-1716) on universal attraction law. Newton, who was a believer who wrote more about biblical interpretation than he did about mathematics and physics ${ }^{39}$, formulated this law and described by it a perfectly coherent heliocentric planetary system, without excluding God from creation. On the contrary, for Newton, God is not confounded with the creation and is omnipresent, acting even on the phenomena level, by the Holy Spirit. For this reason, attraction was regarded also as a spiritual phenomenon by Newton's contemporaries, who did not hesitate to exploit his results in an apologetic sense [as, for instance, the Anglican bishop Richard Bentley (1662-1742), a friend of Newton's, tried to, whom the latter did not hesitate to temperate], being affirmed that the existence of the attraction force would demonstrate God's existence. In exchange, Leibniz saw in the notion of attraction an occult quality or a 'graphic virtue', worthy of one of Moliere's comedies, and he lifts to the rank of principle the fact that a natural cause can only be a mechanical cause, rejecting Newtonian attraction, based on the position that God does not intervene on the phenomena level. This position denotes, however, the deist conception, according to which God concluded His work and no longer intervenes in $\mathrm{it}^{40}$.

IV. The experimental method had a fast impetus by the contribution of Blaise Pascal (1623-1662), who refused to absolutize a science that would have an answer to everything, drawing away from the rationalism of René Descartes (1596-1650) ${ }^{41}$. Abbot Edme Mariotte (1620-1684), a fervent supporter of the experimental way, affirmed in 1678 that an hour's experience sometimes teaches us more than several years' reasonings ${ }^{42}$, and, later, Albert Einstein (1879-1955) said that truth is what withstands the test of experience ${ }^{43}$.

The Orthodoxy, too, is experimental science, based on a therapeutic conduct meant to heal $\operatorname{man}^{44}$. According to this conduct, man's ascetic life goes beyond the notion of a simple moral asceticism and refers to the way of living of a person wanting to commune with God. Based on this reality, knowledge has an important place in the believer's life of asceticism, and the Holy Fathers speak about two knowledge types: natural knowledge and supranatural or spiritual knowledge. The first is of the world, preoccupied with knowing what is around us and relying on reason or intellect and study; the second is divine, concerned with the knowledge of God, starting by spiritual and psychical cleansing and relying on divine Revelation and illumination of the Holy Spirit. Therefore, spiritual and psychical cleansing, indispensable to acquiring supranatural knowledge, requires, beside asceticism, namely

\footnotetext{
declaration, by which he admitted the errors committed by the ecclesial tribunal that judged Galileo Galilei's scientific positions, as result of a study carried out by the Pontifical Council for Culture. In March 2008, Vatican proposed a completion of Galileo's rehabilitation, and a statue was edified for him inside Vatican's walls. In December the same year, on the occasion of the events that marked the $400^{\text {th }}$ anniversary of Galileo's first telescopic observations, Pope Benedict XVI (2005-2013) praised his contributions to the astronomy.

${ }^{39}$ Collins, The Language of God, p. 78 (Collins, Limbajul lui Dumnezeu, pp. 86-87).

${ }^{40}$ Lonchamp, Știință și credință, pp. 88-89. For a while, the Jesuits, as well, as followers of Descartes, fought Newton and ridiculed him in their famous work Dictionnaire de Trévoux, accusing him that he had brought the universe under the influence of magic and calling attraction an occult quality (Lonchamp, Știință și credință, p. 96).

${ }^{41}$ Lonchamp, Știință și credință, pp. 84-85.

${ }^{42}$ Lonchamp, Știință și credință, p. 84.

${ }^{43}$ Einstein, Cum văd eu lumea, p. 305.

${ }^{44}$ Romanidis, Teologia patristică, pp. 41, 115.
} 
beside the practical way, the contemplative way, in other words, contemplative knowledge, which is to say, vision of what cannot be seen by reason or intellect, but only by faith of the heart and prayer of the mind ${ }^{45}$.

Based on these two types of knowledge one can make an analogy also in science. To designate science, Newton used the old designation natural philosophy, so that according to him there is no breakup between science and philosophy, namely between experimental knowledge and knowledge coming by reasoning, after which speculative philosophy may come $^{46}$, yet neither should be mistaken for theology. Thus, Newton is not the messenger of $a$ purely rational science, as some would have wanted; he illustrated what modern epistemologists have come to understand only now, namely, that at the origin of great scientific hypotheses are often metaphysical ideas ${ }^{47}$. Returning to the polemic he had with Leibniz, we can conclude that Newton rejected the mechanist conception of the universe, circulated by cartesianism, and formulated an extraordinary physical-mathematical concept, around which modern physics has been built ${ }^{48}$.

Nevertheless, cartesianism won the day and favoured the promotion of rationalism and, implicitly, of deism, which entailed the emergence of several trends: emergence of free thinking [Anthony Collins (1676-1729)] in England, according to which, from religion was preserved only what seemed reasonable; support of a total dominion of reason [John Toland (1670-1722) in Ireland] over the Holy Scripture and over science; the vision of the Great Architect or of the Great Watchmaker, present at many encyclopaedists [Jean-Baptiste le Rond d'Alembert (1717-1783), Pierre Louis Moreau de Maupertuis (1698-1759) etc.]; the idea of a purely mechanistic universe [Paul-Henri Thiry, Baron d'Holbach (1723-1789)], namely of atheist materialism, from which the $19^{\text {th }}$ century militant atheism will develop ${ }^{49}$. Immanuel Kant is the one who managed, in The Critique of Pure Reason (1781), to limit the

\footnotetext{
${ }^{45}$ About the role of reason and intellect, on the one hand, and of mind and heart, on the other hand, in spiritual life, see Romanidis, Teologia patristică, pp. 25-31.

${ }^{46}$ Lonchamp, Știință și credință, p. 89.

${ }^{47}$ Lonchamp, Știință și credință, p. 91.

${ }^{48}$ Lonchamp, Știință și credință, p. 91.

${ }^{49}$ Lonchamp, Știință și credință, pp. 96-97. Memorable is that the human crew of the first spaceship, Apollo 8, which orbited around the moon, presented, on Christmas Eve, in the year 1968, a live broadcast from the space capsule. On this occasion, the crew members read to the entire world the first ten verses from the first chapter of Genesis. Shortly after this, the famous atheist militant Madalyn Murray O'Hair filed a case against the space agency NASA, for the fact that the federal agents allowed the reading of the passage from the Holy Scripture, referring to the three American astronauts Frank Borman, James Lovell and William Anders. Although the court rejected Murray's request, NASA discouraged such references to faith for the next space missions. Consequently, the fact that Buzz Aldrin, participant in the Apollo 11 mission in the year 1969, when the first moon-landing took place, arranged to take communion on the Moon was never made public. Yet, no one objected in 1844, when Samuel Morse's first telegraphic message was: What hath God wrought? [Collins, The Language of God, p. 160 (Collins, Limbajul lui Dumnezeu, p. 170)]. Atheism grew in intensity, and its greatest supporters, Richard Dawkins and Daniel Dennett, by a skilful marketing strategy, together with their colleagues from the atheist community, even tried to promote the term bright, as alternative to atheist, the implicit conclusion being the use of the term obscurantist to characterize the believer [Collins, The Language of God, p. 161 (Collins, Limbajul lui Dumnezeu, p. 171)]. For the rejection of Richard Dawkins's arguments, but also of atheism, see Collins, The Language of God, pp. 163-167 (Collins, Limbajul lui Dumnezeu, pp. 173-177). Worth noticing is Stephen Jay Gould's position, a fervent militant of evolutionism, who criticizes Dawkins harshly, affirming, among others, that science can work only naturalistic explanations; it can neither affirm, nor deny other types of authors (like God) in other spheres (the moral realm, for instance), see S. J. Gould, "Impeaching a Self-Appointed Judge" (review to Phillip Johnson's book, Darwin on Trial), in Scientific American 267 (1992), pp. 118-121, apud Collins, The Language of God, p. 166 (Collins, Limbajul lui Dumnezeu, pp. 176177).
} 
omnipresent naivete of reason, ironically calling it 'barking reason', separating the domain of natural sciences, in which reason roams fully free, from that of metaphysics. Regarding the latter domain, Kant refuses to accept any 'scientific' proof of God's existence, without annulling at all the faith in God which, according to him, is pointed out from 'practical reason ${ }^{50}$. However, scientism emerges in the $19^{\text {th }}$ century (August Comte), and this trend's defenders (Ernest Renan, Pierre Eugène Marcellin Berthelot) promote principles, such as: science is the only valid authority; only science can found vital truths and engender a new conception on man's destiny; science is devoid of mystery, destroying faith and the supranatural; no faith can exist except that in experiment; rejection of miracle; technocrat ideal, namely entrusting the society's leadership to experts (bankers, engineers etc.), science becoming 'the spiritual basis of social order" ${ }^{, 51}$. A consequence of these positions is, consequently, the flourishing of atheism, in the same $19^{\text {th }}$ century, with Ludwig Feuerbach (putting man in God's place), Karl Marx (socio-politic atheism, total disappearance of religion and formation of a society without social classes) and Friedrich Nietzsche (denial even of the possibility to reflect on God, proclaiming God's death) ${ }^{52}$.

V. The limits of scientific knowledge are recognized by scientists, who admit that the boundary between known and unknown, which science is pushing back, is like the shore of a small island in a sea of unknown. Even if science gets an unlimited future of success after success, none of these will bring the unknowable closer, so that the shore can be remodelled, but finally the sea will never be drained up ${ }^{53}$. It is an obvious fact that the rationality of the universe cannot be explained rationally based on an irrationality ${ }^{54}$.

Actually, faith in God explains the world's rationality, a fact appropriated by scientists who are believers. For those who do not believe, clarifying is the dialogue between a specialist in molecular biology, Robert Pollack, a practicing Jew, and his teacher, rabbi Adin Steinsaltz, on the way his non-believer friends' critique to the book the first had written should be answered: If you know anyone who says that God's Throne is empty and lives in peace with this, then get attached to that person as to a good and trust-worthy friend. But take care: almost all those who say that have already put something or someone on that Throne-usually, themselves 55 .

In the same sense, one can add the answer of metropolitan Nicholas of Mesoghéia and Lavreotikí (Greece), formerly world-famous researcher, given to a group of young people regarding the relation between faith in God and science: ... running after scientific knowledge and truth is actually fascinating. I wish you to taste it. Research is like a dizzying drunkenness. Our world is created with incredible beauty and wisdom. It is worth discovering these two as much as possible. But he should do it with a man's humility, not with the impertinence of a false god. He need to put himself in harmony with his limits ${ }^{56}$.

\footnotetext{
${ }^{50}$ Lonchamp, Știință și credință, p. 97.

${ }^{51}$ Lonchamp, Știință și credință, pp. 105-106.

${ }^{52}$ Lonchamp, Știință și credință, pp. 106-107.

${ }^{53}$ Robert Pollack, Credința biologiei și biologia credinței. Ordine, sens și liber-arbitru în științele medicale moderne, translation from English by Viorel Zaicu, Editura Curtea Veche, București, 2007, pp. 26-27.

${ }^{54}$ Ratzinger, Europa, p. 81.

${ }^{55}$ Robert Pollack, op. cit., pp. 15-16.

${ }^{56}$ Nikoláou, Mitropolítou Mesogaías kai Lavreotikís, Án ypárchei zoí, thélo na zíso, Ékdosi Ierá Mitrópolis Mesogaías kaí Lavreotikís, Athína, 2013, p. 59 (henceforth: Nikoláou, Mitropolítou Mesogaías kai Lavreotikís, Án ypárchei zoí).
} 
Human knowledge, perception and wisdom are neither limitless, nor complete. And even our nature shows us our limits. The Universe presents at its beginning a singularity

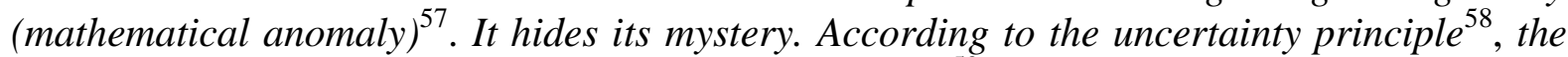
more nature reveals a mystery, the more it hides another ${ }^{59}$.

We are blessed to know what is much and great but condemned not to conquer the infinite and the complete. Yet, this infinite and complete, namely, what is beyond our senses and knowledge, are what lead us to God. Whoever gets dizzied by his knowledge loses God. At that moment, his life looks like a chain, whose every link is also a success. However, the final overall result is a disappointment and a failure. Knowledge is very beautiful, yet insufficient to free you. It has limits, it is overwhelmed. Thus, faith is needed as well. It leads to the infinite and to the complete 60 .

Therefore, one of the great questions interrogating scientists is God's existence. In 1916, a survey was carried out among biologists, physicists and mathematicians, who were asked if they believe in a God actively communicating with people and to Whom they can pray, hoping for an answer. About $40 \%$ of them answered affirmatively. The same survey

\footnotetext{
${ }^{57}$ Singularity in a mathematical sense represents a rupture point for a function, namely a discontinuity to the rest of the function. The term got to be consecrated as well in astrophysics, being used to describe the beginning of the universe under the name of Big Bang, namely the moment when equations lose their sense, and physics' laws are annulled. Today's scientific cosmology proposes as a cosmological scenario the standard model of the Big Bang, and by complex mathematic demonstrations, like those of Roger Penrose and Stephen Hawking, is highlighted the initial singularity, whose existence, however, remains without final answer. Thus, the arising problem is the overcoming of the standard model, as cosmology raises fundamental questions on the universe's origin, existence and final aim. By the Big Bang theory, scientists become increasingly more aware that the answers of science cannot be definitive (Lonchamp, Știință și credință, pp. 112-113). The limits of cosmology are structured as well by Christian theology, which shows that the study of the world, guided by laws of physics in a limited framework, is carried out inside the creation affected by the consequences of primordial sin, so that the reality of the world before sin is known only to those who reach spiritual perfection and holiness, therefore, from an eschatological perspective, since they, too, go through the moment of separation of the soul from the body. Consequently, a new way of being is affirmed, which is a transformation on the personal and cosmic level, according to Jesus Christ's resurrected body, which means the reality of a new physics, regarding the beginnings of the universe as well.

58 This principle stated by Werner Karl Heisenberg, in 1927, designates a physical measurement accuracy margin. In other words, by this principle, also called of indetermination even by Heisenberg, correcting the name of the concept in the second edition of his study, but too late to prevent the spreading of the term uncertainty associated to his principle, states the impossibility of determining simultaneously the position and speed of a moving particle in quantum mechanics, as contrasted with Newtonian classical mechanics' vision, where this fact is perfectly possible regarding the objects of the physical world on the macroscopic level. Impossibility is understood as structural limit and not due to temporary ignorance, eventually correctable in the future. It should be mentioned that the two terms, indetermination and uncertainty, entered the collective scientific conscience, referring to the same Heisenberg's indetermination or uncertainty principle. By his principle, Heisenberg overturned Pierre-Simon Laplace's determinism in one blow and got Einstein to review his thinking [Collins, The Language of God, pp. 79-80 (Collins, Limbajul lui Dumnezeu, pp. 87-88)]. It should be noted that it is Laplace who, to Napoléon Bonaparte's question about God, gave the reply that remained famous: I have no need of this hypothesis [Collins, The Language of God, p. 79 (Collins, Limbajul lui Dumnezeu, p. 87)], and that Einstein initially dismissed the concept of uncertainty, by his famous statement: God does not play dice Collins, The Language of God, pp. 80, 82 (Collins, Limbajul lui Dumnezeu, pp. 88, 91)]; about the fact that Einstein was not so comfortable with quantum mechanics, see Stephen W. Hawking, "Einstein's Dream", in Visul lui Einstein şi alte eseuri, translation from English and foreword by Gheorghe Stratan, Editura Humanitas, București, 2005², pp. 76-90).

${ }^{59}$ Nikoláou, Mitropolítou Mesogaías kai Lavreotikís, Án ypárchei zoí, pp. 59-60.

${ }^{60}$ Nikoláou, Mitropolítou Mesogaías kai Lavreotikís, Án ypárchei zoí, p. 60.
} 
was repeated, word by word, in 1997, and, to the researchers' surprise, the percentage remained almost unchanged, concerning faith in a God of personal dialogue ${ }^{61}$.

Even in the modern and postmodern epoch of cosmology, evolution and human genome, scientists, as Francis Collins, say a resounding yes to a richly satisfying harmony between the scientific and spiritual worldviews, in other words, expressing the conviction that there is no conflict in being a rigorous scientist and a person who believes in a God who takes a personal interest in each one of us. Science's domain is to explore nature. God's domain is in the spiritual world, a realm not possible to explore with the tools and language of science. This domain of God ought to be investigated with the heart, the mind and the soul, and the mind must find a way to embrace both realms ${ }^{62}$. Leader of the International Human Genome Project, who endeavoured for more than a decennium to uncover the DNA chain and draft the human genome map ${ }^{63}$, Francis Collins went through the stages of agnostic and atheist, to reach, by researching the Moral Law in man and several spiritual traditions, the conviction of the existence of the God of Abraham, namely he did not stop at the deistic God of Einstein ${ }^{64}$, but went on to the God of personal relationship with man, becoming disciple of Christ $^{65}$ and following C. S. Lewis' example, he, too, an atheist, formerly ${ }^{66}$. Faith in God, in front of the arguments of Moral Law and of several other aspects, appears more rational than

${ }^{61}$ Collins, The Language of God, p. 4 (Collins, Limbajul lui Dumnezeu, p. 10). The geneticist Francis S. Collins notes that all too often today, scientists are uneasy about admitting their spiritual views [Collins, The Language of God, p. 230 (Collins, Limbajul lui Dumnezeu, p. 240)]. Actually, to the scientists worried that faith in God might suppose a descent into irrationality, a compromise of logic, or even intellectual suicide, Collins tells that of all the possible worldviews, atheism is the least rational [Collins, The Language of God, p. 231 (Collins, Limbajul lui Dumnezeu, p. 241)].

${ }^{62}$ Collins, The Language of God, pp. 6, 199 (Collins, Limbajul lui Dumnezeu, pp. 12, 208).

${ }^{63}$ The human genome consists in man's complex DNA, representing the hereditary code of life. The deciphered DNA appears under the form of a text made up of three billion letters, written in a strange and cryptographic code, made up of four letters. The complexity of the information contained in each cell of the human body is amazing, that a live reading of that code at a rate of one letter per second would take thirty-one years, even if reading continued day and night. Printing these letters out in regular font size on normal bond paper and binding them all together would result in a tower the height of the Washington Monument built in George Washington' memory, which is $169 \mathrm{~m}$ high [Collins, The Language of God, pp. 1-2 (Collins, Limbajul lui Dumnezeu, p. 7)].

${ }^{64}$ Collins, The Language of God, pp. 29, 80 (Collins, Limbajul lui Dumnezeu, pp. 36, 91). Although rejecting the doctrine of a personal God, Einstein was constrained to admit the fact that this doctrine could never be denied, in the literal sense of the word, by science, as this doctrine can take shelter again and again in those domains not yet conquered by scientific knowledge (Einstein, Cum văd eu lumea, pp. 288-289).

${ }^{65}$ As a member of the Evangelical Christian Church [Collins, The Language of God, pp. 146, 178 (Collins, Limbajul lui Dumnezeu, pp. 156, 188)]. About Collins' process of conversion to faith in Christ see his narrative in Collins, The Language of God, pp. 219-227 (Collins, Limbajul lui Dumnezeu, pp. 229-237).

${ }^{66}$ Collins, The Language of God, pp. 16, 20-21, 27 (Collins, Limbajul lui Dumnezeu, pp. 22, 28, 36-37). Worth mentioning is that when he received the leadership of the Human Genome Project, in the place of Jim Watson, Collins was already a man of faith in God, and the fact that he was entrusted this Project, offered him the chance, as he himself confesses, to read God's language, namely to find the intimate details of how humans had come to be. Could I walk away? I have always been suspicious of those who claim to perceive God's will in moments such as this, but the awesome significance of this adventure, and the potential consequences for humankind's relationship with the Creator, could hardly be ignored. Collins will accept the leadership of the respective Project after a long afternoon praying in a little chapel, seeking guidance about this decision. I did not 'hear' God speak - in fact, I have never had that experience. But during those hours, ending in an evensong service that I had not expected, a peace settled over me. A few days later, I accepted the offer. The accomplishment of all the objectives of the Human Genome Project will be announced in April 2003 [Collins, The Language of God, pp. 118-119, 122 (Collins, Limbajul lui Dumnezeu, pp. 127-128, 131)]. 
disbelief ${ }^{67}$. Even if molecular mechanisms, genetic methods and natural selection are made available to explain life, however, there is plenty of divine mystery left in the world, and many people who have considered all the scientific and spiritual evidence still see God's creative and guiding hand at work ${ }^{68}$.

Albert Einstein speaks about cosmic religiosity, based on the world's rationality and superior to the other religious living steps, going beyond the fundamental teaching of any Church, yet representing, at the same time, the strongest and noblest impulse of scientific research ${ }^{69}$. For this reason, he asks himself with awe: What profound belief in the rationality of the world's composition and what aspiration to understanding even an insignificant reflex of the rationality unveiled in this world must have been alive in Kepler and Newton, for them to be able to decipher the celestial mechanics mechanism in the solitary work of many years $?^{70}$ Knowing the faith in God of the two scientists invoked, it is no wonder that Einstein acknowledges, based on one of his contemporaries' testimony, that only deeply religious people are most serious researchers ${ }^{71}$. At the same time, Einstein also evokes an intrinsic reality, existing independently from any observation or measurement ${ }^{72}$. Bernard d'Espagnat (1921-2015) re-examined, in the light of quantum mechanics, the concept of reality, getting to a distinction between empirical reality and independent reality. Empirical reality is defined as the set of phenomena, which reality is breakable into subsystems and allowing scientific study. Independent reality is situated outside spatiality-temporality, being neither explorable, nor describable by scientific procedures. This does not mean that what cannot be known scientifically, cannot be known at all, because this reality leaves visible traces on our empirical world.

Thus, according to Jean-Pierre Lonchamp, in this point, d'Espagnat separates himself from Einstein $^{73}$, and philosophers reach the same conclusions before scientists. In philosophical terms, the domain of independent reality is the 'domain of existence', defined by Baruch Spinoza (1632-1677) as what exists per se, namely all that is not a quality of something, nor someone's phantasy. Spinoza does not hesitate to call God this existence per se, to mark the difference to the world of phenomena, and d'Espagnat borrows from him,

${ }^{67}$ Collins, The Language of God, p. 30 (Collins, Limbajul lui Dumnezeu, p. 37). In another place, Collins affirms: I had reached the conclusion that faith in God was much more compelling than the atheism I had previously embraced [Collins, The Language of God, p. 198 (Collins, Limbajul lui Dumnezeu, pp. 207-208)], and after twenty-eight years as a believer, the Moral Law still stands out for me as the strongest signpost to God [Collins, The Language of God, p. 218 (Collins, Limbajul lui Dumnezeu, p. 228)].

${ }^{68}$ Collins, The Language of God, p. 106 (Collins, Limbajul lui Dumnezeu, p. 115). The comparison of chimp and human sequences (the decoding of the human genome and that of the chimpanzee shows that people and chimpanzees are $96 \%$ identical, man having 23 pairs of chromosomes, and the chimpanzee 24), interesting as it is, does not tell us what it means to be human. In Collins' opinion, DNA sequence alone, even if accompanied by a vast trove of data on biological function, will explain certain special human attributes, such as the knowledge of the Moral Law and the universal search of God [Collins, The Language of God, pp. 136-137, 139140 (Collins, Limbajul lui Dumnezeu, pp. 146-147, 149-150)].

${ }^{69}$ Einstein, Cum văd eu lumea, pp. 254-256, 268. In relation with cosmic religiosity, Einstein was asking himself: How can cosmic religion be transmitted from man to man if it cannot lead to a defined concept of God (geformter Gottesbegriff) and theology? In his answer, Einstein affirms that this can be done by art and science, which have the role of awakening and keeping this feeling alive in those able to live it (Einstein, Cum văd eu lumea, p. 255).

${ }^{70}$ Einstein, Cum văd eu lumea, p. 256.

${ }^{71}$ Einstein, Cum văd eu lumea, p. 256.

${ }^{72}$ Lonchamp, Știință și credință, p. 123.

${ }^{73}$ Lonchamp, Știință și credință, p. 124. 
sometimes, the same expression ${ }^{74}$. Independent reality is considered not just matrix of the phenomena, but also matrix of values, like beauty, sacred etc. For instance, art uses sensible realities, matters, colours, but the artist's work refers to 'something' mysterious hiding behind perceivable signs, namely to a reality behind things. In this way, the reflections of a scientist, representative of contemporary science, meet the domain of theology, in the preoccupations of the Roman-Catholic priest Hans Urs von Balthasar (1905-1988), who looks at the divine Revelation not just under its aspect of truth and goodness, but also under its aspect of beauty as reflection of divine glory. To conclude, the metaphysical problem of the Being or of God is worth being asked, starting from the empirical reality, so from science, by searching for the One in the multiple. This metaphysical approach, glimpsed by the pre-Socratics, revealed in The Old and The New Testament, is rediscovered by eminent scientists and philosophers, in the light of contemporary science ${ }^{75}$.

VI. The fact of creation remains in the scientists' attention, constrained by fifteen physical constants (including speed of light, power of the weak and strong nuclear forces, different parameters associated with electromagnetism, force of gravity), whose values cannot be pointed out, and the chance that all of these constants would take on the values necessary to result in a stable universe capable of sustaining complex life forms is almost infinitesimal $^{76}$. The evaluation of these constants led to the anthropic principle formulation, stating that the universe is made to favour the emergence of men and their life on earth ${ }^{77}$, while the Big Bang theory constrains scientists to ask themselves what was before this event or who is responsible of its occurrence, proving the limits of science as no other phenomenon has done. In the endeavour to provide answers to the questions above, glimpsing the closeness between Big Bang and the creation out of nothing, both being, in fact, the result of a miracle, enough agnostics get to sound downright theological ${ }^{78}$, already famous both in science and various spiritual traditions, being the astrophysicist Robert Jastrow's remark: At this moment it seems as though science will never be able to raise the curtain on the mystery of creation. For the scientist who has lived by his faith in the power of reason, the story ends like a bad dream. He has scaled the mountains of ignorance; he is about to conquer the highest peak; as he pulls himself over the final rock, he is greeted by a band of theologians who have been sitting there for centuries ${ }^{79}$. In fact, the existence of a universe, as we know it, geneticist Francis S. Collins affirms, rests upon a knife edge of improbability ${ }^{80}$ and there is no question that the synchronization of all the constants and physical laws to make intelligent

\footnotetext{
${ }^{74}$ Lonchamp, Știință și credință, p. 124.

${ }^{75}$ Lonchamp, Știință și credință, p. 125.

${ }^{76}$ Collins, The Language of God, p. 74 (Collins, Limbajul lui Dumnezeu, p. 82).

${ }^{77}$ See J. D. Barrow, F. J. Tipler, The Anthropic Cosmological Principle, Oxford University Press, New York, 1986; Jean-Michel Maldamé, Christos pentru întreg universul. Pentru o colaborare între știință și credință, Editura Cartimpex, Cluj-Napoca, 1999, pp. 91-128.

${ }^{78}$ Collins, The Language of God, p. 66 (Collins, Limbajul lui Dumnezeu, p. 74). Actually, the agnostics who seriously tried to consider all the evidence for and against God's existence, and a rather distinguished list it is, have unexpectedly converted themselves to belief in God [Collins, The Language of God, p. 168 (Collins, Limbajul lui Dumnezeu, p. 179)]; for the philosophers' case, see Rico Vitz (ed.), Intoarcerea spre Răsărit. Filosofi contemporani și credința creștină veche, translation from English by Mihai-Silviu Chirilă, Editura Renașterea, Cluj-Napoca, 2015.

${ }^{79}$ Robert Jastrow, God and the Astronomers, Ed. W. W. Norton, New York, 1992, p. 107 (henceforth: Jastrow, God and the Astronomers).

${ }^{80}$ Collins, The Language of God, p. 73 (Collins, Limbajul lui Dumnezeu, p. 81).
} 
life possible is potentially a theological issue ${ }^{81}$. In this sense, Stephen Hawking, cited by Ian Barbour, affirms: the odds against a universe like ours emerging out of something like the Big Bang are enormous. I think there are clearly religious implications ${ }^{82}$. Thus, for the scientists inclined to consider a theistic perspective, the Anthropic Principle certainly provides an interesting argument in favour of a Creator $^{83}$.

Returning to the dialogue of Metropolitan Nicholas, cited above, with the group of young men, one of the questions asked by them was: But, today, scientists speak about the theory of everything in physics ${ }^{84}$, about multiple universes ${ }^{85}$, about feeling the beginning and the ends of the world, about elucidating the mystery of life, about an automatic birth, about mapping the genes' secrets, about elucidating the encephalic mechanisms and other related problems. Do not all these show that knowledge tends to the infinite? ${ }^{86}$ The Greek hierarch's answer is as conclusive as possible: It tends, but asymptotically. The term is scientific. It means we will never attain [the infinite] and let me clarify things a little. The theory of everything is a theory that is rather a term than a reality. At the same time, a success is not the mapping of the genome, but deciphering it would have been a success. Similarly about life. Its secret is not to know its mechanisms, but how we could avoid disease, old age, death. Only then we would have succeeded in something. A little humility is needed. Science helps reach an approximate infinite, an approximate eternity and an approximate perfection. Yet, the distance from there to the infinite, to the eternity and to perfection is huge. It is bigger than the distance from them to what is little, recent, imperfect. Knowledge is a two-edged knife. It either creates the deceptive illusion of perfection and of the whole, therefore, it catches you in the trap of the world of limits, or lets you suppose a bit more, consequently, opens for you the way to the spaceship of faith ${ }^{87}$.

VII. Based on the above and on the specialized bibliography one can note several aspects, equally representing subjects requiring deep studies.

1) Seeing in the Big-bang a confirmation, regarding the fact of creation, highlights $a$ naive concordism, but it does not represent a mind-blowing theory, as the universe could

${ }^{81}$ Collins, The Language of God, p. 75 (Collins, Limbajul lui Dumnezeu, p. 83).

${ }^{82}$ I. G. Barbour, When Science Meets Religion, Ed. Harper Collins, New York, 2000, apud Collins, The Language of God, p. 75 (Collins, Limbajul lui Dumnezeu, p. 83).

${ }^{83}$ Collins, The Language of God, p. 78 (Collins, Limbajul lui Dumnezeu, p. 86).

${ }^{84}$ Or the theory unifying all the interactions, also called theory of everything, remains a physicists' dream, impossible to probe experimentally due to reduced technological possibilities. This theory tries to explain the existence of the universe, small and large, noticing a dialectics of entirety to parts. The whole is more than the sum of the parts. The cell is more than a cluster of particles. In the entirety appear new properties, that the constituents do not have (Lonchamp, Știință și credință, p. 119). It should be mentioned that the four forces or fundamental interactions in nature are: gravitational force, responsible of the attraction between masses; electromagnetic force, assuring the atoms' cohesion, linking nuclei to the electrons 'gravitating' around them; the nuclear force or strong interaction force, exerted between nuclei constituents and assuring their cohesion; the weak interaction force, causing the spontaneous disintegration of certain particles and intervenes in natural radioactivity phenomena (Lonchamp, Știință și credință, p. 112; see also Stephen W. Hawking, Scurtă istorie a timpului. De la Big Bang la găurile negre, translation from English by Michaela Ciodaru, Editura Humanitas, București, 2001 ${ }^{3}$, pp. 23-27).

${ }^{85}$ After the theory of parallel universes there came to be formulated the theory of multiple universes, so that a multiple universe could contain an infinite number of universes, and each of these universes has different laws of physics. The consequence of the meeting of two universes would produce a Big Bang. At the basis of this theory is the membrane theory, considered the most recent version of the string theory (2008).

${ }^{86}$ Nikoláou, Mitropolítou Mesogaías kai Lavreotikís, Án ypárchei zoí, p. 60.

${ }^{87}$ Nikoláou, Mitropolítou Mesogaías kai Lavreotikís, Án ypárchei zoí, p. 61. 
have not existed, since it does not have in itself the reasons of its existence. Therefore, it becomes plausible to owe its existence to a being that escapes randomness and whom nothing prevents us from calling the creative God (Jean-Pierre Lonchamp ${ }^{88}$.

2) The universe appears as a very particular one, with fundamental constants of physics which, if they had had other values, they would have prevented the existence of any life form, all the more of man (the anthropic principle). Consequently, all happens as if these very particular conditions have been chosen by an agent exterior to the universe, whom many consider to be an intelligent God, capable of making the necessary choices for man to see the light of day ${ }^{89}$. Although the anthropic principle is not a scientific one, it raises metaphysical problems, which enthuse scientists ${ }^{90}$. The initial state of the universe must have been, indeed, very well chosen, if the hot Big Bang model was correct then, at the beginning of time, as Stephen Hawking affirms. It would be very hard to explain why the universe had to begin exactly this way, except if it was an act of God, Who intended to create beings like $u s^{91}$.

3) One can note, as a sign of the times, the fact that more and more scientists, finally ridding themselves of the taboo that tended to close them in their speciality, do not hesitate to propose publicly, in their daily practice, absolutely fundamental metaphysical problems ${ }^{92}$.

4) Logical empiricism or neo-positivism, which recorded an impetus in the $20^{\text {th }}$ century and endeavouring to provide a scientific representation of the world, had to face Karl Popper' criticism, based on two ideas: a) science cannot be reduced to simple observation statements; scientific facts are always impregnated by theory, so that theories transcend the experience, and if the respective theories are left aside, under the pretext that they are metaphysical, then science itself is destroyed; actually, from Thales to Einstein, metaphysical ideas are the ones that opened the way; b) criticism of induction: induction is a natural tendency of the human spirit, and its validity is indemonstrable, being impossible for logic to verify it; thus, a statement that would like to be general, will never be verifiable by the observer, as we can never be sure that the inventory has been exhaustive ${ }^{93}$. According to this supposition, no one can claim 'that he knows', in an absolute sense, that God does not exist. At the most, God's non-existence can be taken as a working hypothesis, based on which one can try to explain the universe. In essence, modern science is in this situation. However, such a methodological approach is aware of its limits. Clearly, the hypotheses stage cannot be passed over, and, as evident as an atheist explanation of the universe might appear, this will never lead to the scientific certainty according to which God does not exist ${ }^{94}$.

5) Crisis moments in scientific research lead to change of paradigm and scientific revolution (T. S. Kuhn), as it happened when the geocentrism of those of yore was replaced by Copernicus' heliocentrism, or classical mechanics by quantum mechanics; sometimes the paradigm is totally replaced, as it happened for Ptolemeus' geocentric geometry, at other times, the disappearance is not total, for instance, Einstein's relativist mechanics did not disprove classical mechanics, remained valid in its domain ${ }^{95}$.

\footnotetext{
${ }^{88}$ Lonchamp, Știință și credință, p. 127.

${ }^{89}$ Lonchamp, Știință și credință, p. 127.

${ }^{90}$ Lonchamp, Știință și credință, p. 128; Collins, The Language of God, pp. 71-78 (Collins, Limbajul lui Dumnezeu, pp. 79-86).

${ }^{91}$ Stephen W. Hawking, op. cit., p. 149.

${ }^{92}$ Lonchamp, Știință și credință, p. 129.

${ }^{93}$ Lonchamp, Știință și credință, pp. 132-133.

${ }^{94}$ Ratzinger, Europa, p. 73.

${ }^{95}$ Lonchamp, Știință și credință, pp. 135-136.
} 
6) Scientific certainty gets to relativization of scientific truths (Jean-Pierre Lonchamp); a statement is true or false only inside a well-defined conceptual system, endowed with axioms or basic postulates, in which the sense of the terms used is delineated carefully; contemporary epistemology shows that science progresses not accumulating truths discovered one after the other but eliminating errors, which shows that scientific truths are fragile and provisional (Euclidian geometry theories stop being true in a geometry starting from other axioms, for example, Riemann's geometry; Newtonian dynamics laws stop being valid in the framework of Einstein's mechanics etc. $)^{96}$.

7) Pure social or humanitarian research hardly finds financial support; although states' research policy is guaranteed by scientists, with the title of experts in deliberative forums, there are always some of them to give the green light to sinister events ${ }^{97}$. Einstein's warning remains valid: we need to be careful and not overestimate science and the scientific methods when it comes to humanitarian problems; and we must not believe that experts are the only ones allowed to give a verdict in matters of organization of the society ${ }^{98}$.

8) Into so-called the Christian world, although there is total agreement about the general principles, especially regarding the dignity of the human person, divergences emerge when passing from principles to concrete applications ${ }^{99}$.

9) One can note an insistent promotion of the concordism, according to which there should be perfect harmony between the affirmations of the Bible and those of science or, in other words, religious truths should be confirmed based on scientific truths. This kind of concordism comes from the Antiquity and has continued to our days: Blessed Augustin does not hesitate to support his considerations on the soul by demonstrations taken from geometry; other authors assimilated the six days of creation described in the Holy Scripture with successive geological periods, yet, these extremely long time intervals are unimaginably beyond individual experience ${ }^{100}$; the Big Bang theory has been interpreted by some as a decisive confirmation of the idea of creation [the historian Pierre Chaunu affirmed the concordance between Big Bang and Fiat Lux of the Bible; the astrophysicist Trinh Xuan Thuan appreciates that the idea of the birth ex nihilo, which used to belong to religion yesterday, seems to have found scientific support in cosmology; the reformed theologian Jürgen Moltmann launched a project to synthesize the evolutionist theory and the fact of creation, but he is not alone in this attempt (geneticist Francis S. Collins ${ }^{101}$, astrophysicist

\footnotetext{
${ }^{96}$ Lonchamp, Știință și credință, p. 147.

${ }^{97}$ Lonchamp, Știință și credință, p. 152.

${ }^{98}$ Einstein, Cum văd eu lumea, p. 297.

${ }^{99}$ Lonchamp, Știință și credință, p. 154.

${ }^{100}$ Collins, The Language of God, p. 148 (Collins, Limbajul lui Dumnezeu, p. 158). It ought to be mentioned that in support of the evolutionist theory, the authors operate with formulations like let us imagine, probably etc. [Collins, The Language of God, pp. 192-193 (Collins, Limbajul lui Dumnezeu, pp. 201-202)], which indicates the support of some aspects and stages from the intentional perspective of the respective theory.

${ }^{101}$ I have to agree. The Big Bang cries out for a divine explanation. It forces the conclusion that nature had a defined beginning. I cannot see how nature could have created itself. Only a supernatural force that is outside of space and time could have done that... In fact, the God hypothesis solves some deeply troubling questions about what came before the Big Bang, and why the universe seems to be so exquisitely tuned for us to be here... There are good reasons to believe in God, including the existence of mathematical principles and order in creation. They are positive reasons, based on knowledge, rather than default assumptions based on (a temporary) lack of knowledge [Collins, The Language of God, pp. 67, 81, 93 (Collins, Limbajul lui Dumnezeu, pp. 75, 89, 101)]. In my view, evolution may have been God's elegant plan for creating humankind [Collins, The Language of God, p. 146 (Collins, Limbajul lui Dumnezeu, p. 156)]. Science cannot be used to justify discounting the great monotheistic religions of the world, which rest upon centuries of history, moral
} 
Robert Jastrow $^{102}$, practicing Orthodox Christian biologist Theodosius Dobzhansky ${ }^{103}$, biochemist and Anglican priest Arthur Robert Peacocke, the Jesuit Pierre Teilhard de Chardin, the latter being known as geologist, palaeontologist, physicist, anthropologist and Romano-Catholic theologian etc.) $]^{104}$.

10) One can note that there is a resistance of people to accept the theory of evolution, as it is presented by scientists today ${ }^{105}$.

11) The fact of the creation of the world, and implicitly of man, by God ${ }^{106}$, is put in balance with the theory of the Intelligent Plan and the theistic evolution ${ }^{107}$, for the last being

philosophy and the powerful evidence provided by human altruism. It is the hight of scientific hubris to claim otherwise. For this reason, a fully harmonious synthesis must be possible between God's existence and the theory of evolution [Collins, The Language of God, p. 169 (Collins, Limbajul lui Dumnezeu, p. 179)].

${ }^{102}$ Now we see how the evidence of the domain of astronomy leads to a biblical vision on the origin of the world. Details differ, yet, the essential elements and the astronomic and the biblical statements on the 'Genesis' are identical; the chain of events leading to man began unexpectedly at a well-defined moment, by an explosion of light and energy (Jastrow, God and the Astronomers, p. 14).

${ }^{103}$ Nothing in biology makes sense except in the light of evolution [Collins, The Language of God, p. 141 (Collins, Limbajul lui Dumnezeu, p. 150)].

${ }^{104}$ Lonchamp, Știință și credință, p. 155; Nicolae Vladimir Dobre, De la credință la știință și innapoi la credință. Puțină teologie pentru ingineri, dar nu numai pentru ei, Editura de suflet, București, 2011, pp. 84-86. In fact, even Charles Darwin himself lived in ambiguity, oscillating between the state of agnostic and that of theist [Collins, The Language of God, p. 97 (Collins, Limbajul lui Dumnezeu, p. 107)]. Moreover, one can remind as well the doubt or the test foreseen by Darwin himself for his theory: to suppose that the eye with all its inimitable contrivances for adjusting the focus to different distances, for admitting different amounts of light, and for the correction of spherical and chromatic aberration, could have been formed by natural selection, seems, I confess, absurd in the highest degree (C. Darwin, The Origin of Species, Ed. Penguin, New York, 1958, p. 171). Then he adds the contradiction: if it could be demonstrated that any complex organ existed, which could not possibly have been formed by numerous, successive, slight modifications, my theory would absolutely break down. But I can find no such case (ibidem, p. 175). Yet, from these assertions, a series of questions is born, to which the theory of evolution has not been able to answer convincingly: Why do the living beings have the sense of sight? Why do they need to see the light? Why the alternance between light and darkness? etc.

${ }^{105}$ In 2004, the organisation called Gallup carried out several surveys on the evolutionist theory and faith in God. In one of them, the question was: Which of the following affirmations is closer to your conceptions on the origin and evolution of humans? (1) Humans have evolved in millions of years from less advanced forms of life, yet, God supervised this process. (2) Humans evolved in millions of years from less advanced forms of life, but God played no role in this process. (3) God created humans nearly in today's form at a point in the last ten thousand years. The answers of the representative sample of Americans were: $45 \%$ chose variant $3 ; 38 \%$ opted for variant 1 , and $13 \%$ expressed themselves in favour of variant 2 . It should be noted that these statistics remained almost unchanged during the last 20 years [Collins, The Language of God, pp. 146-147 (Collins, Limbajul lui Dumnezeu, pp. 156-157)].

${ }^{106}$ On the Christian cosmology in parallel with the theories of modern physics, see Lucian-Răzvan Petcu (Pr.), Cosmologia creștină și teoriile fizicii moderne, Editura Sophia, București, 2008.

${ }^{107}$ Collins is the promotor of the term and conception of theist evolution (supported by serious biologists, simultaneously, serious believers, including Asa Gray, Darwin's main supporter in the United States, Theodosius Dobzhansky, artisan of the $20^{\text {th }}$ century evolutionist thinking, and pope John Paul II), to fight both atheism, and the Intelligent Plan movement. Appeared in 1991, to counterbalance the lack of success of the teaching of creationism in the American schools, this movement is supported by Phillip Johnson, Christian lawyer at Berkeley University, California, Michael Behe, molecular biology professor, and William Dembski, mathematician specialized in the theory of informatics [Collins, The Language of God, pp. 181-195, 199 (Collins, Limbajul lui Dumnezeu, pp. 190-206, 209)]. In 2005, the president of the United States announced his partial support for the Intelligent Plan theory, affirming that schools ought to include this perspective in their curriculum as well, when the theory of evolution is taught [Collins, The Language of God, p. 181 (Collins, Limbajul lui Dumnezeu, p. 190)]. Regarding the typical version of the theistic evolution, six premises have been formulated (see Collins, Limbajul lui Dumnezeu, p. 210 p. 200), of which I cite the last: humans are also unique in ways that defy evolutionary explanation and point to our spiritual nature. This includes the existence of the 
proposed (Francis S. Collins) as well the term of BioLogos ${ }^{108}$. Collins starts in the formation of the term from the Greek words Bios (= life) and $\lambda o$ jo $(=$ word), referring the latter to the significance of the Word (Logos) for the Christian believers, Who is synonymous with God, as powerfully and poetically expressed in those majestic opening lines of the Gospel of John: 'In the beginning was the Word, and the Word was with God, and the Word was God' (John 1: 1). Therefore, for Collins, the term 'BioLogos' expresses the belief that God is the source of all life, and that life expresses the will of God $^{109}$, Who used the procedure of evolution.

12) The theological faith based on the Revelation shows that God is mystery and remains mystery, which will never be encompassed by reason. Along with the theological faith, also called Christian, there is also a philosophical or metaphysical faith, based on reason, not on the mind, by which faith man gets to accept a God, understood as principle and cause of everything that exists. Yet, the God Who uncovered Himself by Revelation, as being One, but in three Persons or Hypostases, cannot just be identified with the God of metaphysics ${ }^{110}$.

13) The evidence of Jesus Christ's existence and the authenticity of the four Gospels, confirming that Jesus Christ was not just a man, not even a great spiritual teacher, but God's Son, true God and true Man ${ }^{111}$, as only He could suffer and die for our sins, because He is Man, and could do this perfectly, because He is God $^{112}$. According to Saint Maximus the Confessor, man needs to get to unity of knowledge in Christ, as $\mathrm{He}$ is the key and fundament of the unity of knowledge of the whole creation. Man can discover the reasons of creation by cultivating the relation with the divine Logos, Who is the Source of all that exists and to Whom all the reasons refer. Therefore, the discovery of the world's reasons represents a stage of the spiritual life, by the participation to life in Christ. What makes a difference between man and the rest of creation is the possibility of deification of man by divine grace. Thus, the discovery of the world's reasons is no less a theological approach than the

Moral Law (the knowledge of right and wrong) and the search for God, these two facts characterizing all human cultures throughout history [Collins, The Language of God, p. 200 (Collins, Limbajul lui Dumnezeu, p. 210)]. For the criticism expressed against the theistic evolution, see R. C. Newman, "Some Problems for Theistic Evolution", in Perspectives on Science and Christian Faith 55 (2003), pp. 117-128; Collins, The Language of God, pp. 201-206 (Collins, Limbajul lui Dumnezeu, pp. 211-217).

108 Collins, The Language of God, p. 203 (Collins, Limbajul lui Dumnezeu, p. 213).

109 Collins, The Language of God, pp. 203-204 (Collins, Limbajul lui Dumnezeu, pp. 213-214). BioLogos doesn't try to wedge God into gaps in our understanding of the natural world; it proposes God as the answer to questions science was never intended to address, such as 'How did the universe get here?', 'What is the meaning of life?', 'What happens to us after we die?' Unlike Intelligent Design, BioLogos is not intended as a scientific theory. Its truth can be tested only by the spiritual logic of the heart, the mind and the soul [Collins, The Language of God, p. 204 (Collins, Limbajul lui Dumnezeu, pp. 214-215)]. In that context, evolution would appear to us to be driven by chance, but from God's perspective the outcome would be entirely specified. Thus, God could be completely and intimately involved in the creation of all species, while from our perspective, limited as it is by the tyranny of linear time, this would appear a random and undirected process [Collins, The Language of God, p. 205 (Collins, Limbajul lui Dumnezeu, p. 216)].

${ }^{110}$ Lonchamp, Știință și credință, pp. 157-158.

${ }^{111}$ C. S. Lewis, Mere Christianity, Barbour and Company, Westwood, 1952, p. 45, apud Collins, The Language of God, p. 225 (Collins, Limbajul lui Dumnezeu, p. 235); see also L. Strobel, The Case for Christ, Ed. Zondervan, Grand Rapids, 1998; C. L. Blomberg, The Historical Reliability of the Gospels, Ed. Intervasity, Downers Grove, 1987; G. R. Habermas, The Historical Jesus: Ancient Evidence for the Life of Christ, College Press, New York, 1996; F. F. Bruce, The New Testament Documents, Are They Reliable? Eerdmans Publishing Co., Grand Rapids, 2003.

112 C. S. Lewis, op. cit., p. 50, apud Collins, The Language of God, pp. 222-224 (Collins, Limbajul lui Dumnezeu, pp. 232-233). 
knowledge of God, because, despite the radical distinction between created and uncreated, the knowledge of the world and of all that exists, which He invites us to, is realized by God's grace, namely by a theological way ${ }^{113}$.

VIII. In front of the dilemmas triggered by the scepticism of certain scientists, a majority or a minority, let us not ignore the more insidious and widespread trap, consisting in the appearing of a spiritually dead, secular faith, which strips out all of the numinous aspects of traditional belief, presenting a version of spiritual life that is all about social events and/or tradition, and nothing about the search for God $^{114}$.

Actually, even since the $14^{\text {th }}$ century, namely since Saint Gregory Palamas' time, the Orthodox Church had a choice to make: on the one hand, a unitary conception on man, founded on the Bible, an affirmation of the immediate efficacy of the saving grace in all the human activity domains; on the other hand, an intellectualist spiritualism which affirmed the independence or at least the autonomy of the human intellect to matter and which denied the fact that, even since the earth, man's real deification is possible. We can easily understand that the secularization of the modern Times sprung from this last standpoint ${ }^{115}$.

Due to secularization, one can note the attitude of some consisting in turning their back to the faith, concluding that science has rendered spiritual life no longer necessary and traditional religious symbols can now be replaced by engravings of the double helix on our altars, and others' tendency to see science as a threat to God. Yet, both of these choices are profoundly dangerous. Both deny truth. Both will diminish the nobility of humankind. Both will be devastating to our future. And both are unnecessary. The God of the Bible is also the God of the genome. He can be worshiped in the cathedral or in the laboratory. His creation is majestic, awesome, intricate and beautiful - and it cannot be at war with itself. Only we imperfect humans can start such battles. And only we can end them ${ }^{116}$.

From the perspective of the Orthodoxy, namely from the philokalical vision of the relations between theology and science, in other words, between spiritual knowledge or knowledge in the Holy Spirit and scientific knowledge, a science illumined by a spiritual discernment becomes a treasure for the entire mankind ${ }^{117}$.

IX (Conclusions). Worth praising is the fact that numerous scientists have come to accept, nowadays, knowingly or not, the standpoint of the Holy Church Fathers ${ }^{118}$, who distinguish between worldly knowledge or the wisdom coming from the outside or from below $(\theta v \rho \alpha \theta \varepsilon v \sigma o \varphi i \alpha)$, whose work deals with the created reality, and spiritual knowledge or wisdom from Above, relying on the charismatic experience and giving man the possibility to know God's presence in the world, by the uncreated divine energies ${ }^{119}$. Saint Gregory

\footnotetext{
${ }^{113}$ Ionescu, Teologie Ortodoxă și Știință, p. 186.

${ }^{114}$ Collins, The Language of God, p. 41 (Collins, Limbajul lui Dumnezeu, p. 48).

115 John Meyendorff (Pr.), Sfântul Grigorie Palama și mistica ortodoxă, translated by Angela Pagu, Editura Enciclopedică, București, 1995, pp. 141-142.

${ }^{116}$ Collins, The Language of God, p. 211 (Collins, Limbajul lui Dumnezeu, pp. 221-222).

117 Ionescu, Teologie Ortodoxă și Știință, p. 236; see also Răzvan Ionescu, "Repere privind o (încercare de) abordare filocalică a raporturilor dintre teologie și știință”, in Tabor VIII/10 (2014), p. 95.

118 This standpoint of the Holy Fathers relies on the teachings of the Saint Apostles Paul (see I Cor. 1: 18, 31; 2: 6-10, II Cor. 1: 12) and James (3: 13-17).

119 See Panag. K. Chrístou, "I énnoia tís diplís gnóseos katá tón Grigórion Palamán”, in Anátypon ek tís Epistimonikís Epetirídos tís Theologikís Scholís, En Thessaloníki, 1963, pp. 3-12? CH. Terézi, Grigórios
} 
Palamas distinguishes between the uncreated divine energies, which are God's grace manifested in the world, and the energies specific of the creatures, which are created energies. Created energies are accessible and can be acquired by most people by the approaches for knowledge from inside the created world. The uncreated energies are accessible according to certain gifts or charismata from the Uncreated, and the condition for receiving them is to cleanse our heart from sinful passions, namely man's progress on the way of dispassion, getting not just to feel God's presence, by different signs, but also to contemplate it, namely to see it as the supra-cosmic and uncreated Light, according to the Saints' testimony ${ }^{120}$. Based on the distinction above, between created and uncreated energies, Saint Gregory Palamas brings to man's attention, by his own experience of the holy-spiritual life, the difference between natural and supra-cosmic gifts. God offers the first to all, without distinction, by nature, while the supra-cosmic or spiritual gifts are offered by the Holy Spirit, directly, to those who stand out by their virtue ${ }^{121}$. By the natural gifts, man investigates the reasons of the things that exist and recognizes God's power, wisdom and presence. By the supra-cosmic gifts, man ascends to the knowledge of God, which means theology ${ }^{122}$.

Science has been defined as the only legitimate way to investigate the natural world. Although experiments can fail spectacularly, interpretations of experiments can be misguided, and science can make mistakes, however, science, by its nature, is self-correcting. Yet, no major fallacy can long persist in the face of a progressive increase in knowledge $e^{123}$.

Thus, scientific knowledge or worldly wisdom has its limits, being accepted that science alone is not enough to answer all the fundamental questions related to the sense of man's existence, God's reality, the possibility of a life beyond death, man's spiritual states etc. Although an atheist, for instance, could claim that these questions are unanswerable and consequently irrelevant, however, this does not echo the human experience of most people. Not accidentally, Albert Enstein wrote that science without religion is lame, religion without science is blind ${ }^{124}$, and John Polkinghorne turns to the comparison with music, irreducible to the scientific perspective alone, according to which music is nothing but vibrations in the air, impinging on the eardrums and stimulating neural currents in the brain, because one could not explain how this banal sequence of temporal activity has the power to speak to our hearts of an eternal beauty ${ }^{125}$.

In consequence, the spiritual vision is another way of finding the truth, and the scientists denying this are warned to be aware of the limits of their own tools, used to

Palamás Methodologiká. I theoría perí «enóseon-diakríseon»,; Ionescu, Teologie Ortodoxă și Știință, pp. 193236.

${ }^{120}$ Ionescu, Teologie Ortodoxă și Știință, p. 205. Natural energies are useful to man, nourishing him and helping him to survive biologically in this earthly life, while the supernatural presence of the uncreated divine energies opens man's spiritual horizon and offers him a food structuring him and preparing him for the eternal life (Ionescu, Teologie Ortodoxă și Știință, p. 206).

${ }^{121}$ Sfântul Grigorie Palama, Triade II, 1, 25, apud Ionescu, Teologie Ortodoxă și Știință, p. 211. In this point, it is worth reminding Saint James the Apostle's word: If any of you lacks wisdom, let him ask from God, who gives to all liberally and without reproach, and it will be given to him. But let him ask in faith, with no doubting (James 1: 5). In this way, man will acquire as a gift also the wisdom that is from above, which is first pure, then peaceable, gentle, willing to yield, full of mercy and good fruits, without partiality and without hypocrisy (James 3: 17).

${ }^{122}$ Panag. K. Chrístou, op. cit., p. 10.

${ }^{123}$ Collins, The Language of God, p. 228 (Collins, Limbajul lui Dumnezeu, p. 238).

${ }^{124}$ Einstein, Cum văd eu lumea, p. 286.

${ }^{125}$ J. Polkinghorne, Belief in God in an Age of Science, Yale University Press, New Haven, 1998, pp. 18-19, apud Collins, The Language of God, p. 228 (Collins, Limbajul lui Dumnezeu, pp. 238-239). 
highlight their own version of the truth ${ }^{126}$. Actually, the promotion of the concordism reminded above, by which a direct agreement is searched for between a text of the Holy Scripture and scientific knowledge, is not found at the Holy Fathers, who do not use this methodology, precisely because observing the convergences between theological and scientific statements is no aim per se, but everything needs to be beneficial to edify theology, namely the living of the unity of knowledge in Christ ${ }^{127}$. For this reason, one cannot find, for instance, in Saint Basil the Great's Hexameron, neither concordism nor discordism ${ }^{128}$. He makes the difference between observations from natural sciences and their consecrated philosophical interpretations, which he nevertheless signalizes and condemns if they do not converge with the theological perspective, in other words, with the divine Revelation, as the texts of the Holy Scripture are inspired by God and the knowledge in them is at a deeper level than human knowledge ${ }^{129}$.

Therefore, Moses, says Saint Basil the Great, made worthy, just like the angels, to see God face to face, tells us what he heard from God. Let us listen, consequently, to the words of the truth, pronounced 'not with persuasive words of human wisdom' (1 Cor. 2: 4), but 'with teachings of the Spirit' (1 Cor. 2: 15), meant not to draw praises from those who listen to them, but to bring salvation to those instructed by them ${ }^{130}$. To understand the spirit of the above, the same Holy Father comes with the following mentions, which can also be the final conclusions of this study: Much has been said by the Greek philosophers about nature, but none of their ideas remained unshaken and not upturned... These philosophers, not knowing God, did not put at the foundation of the creation of the universe a rational cause, on the contrary their ideas on the creation of the world are the conclusions of their initial ignorance regarding God. For this reason, some, to explain the creation of the world, ran to material hypotheses, attributing to the elements of the world the cause of the creation of the universe; others imagined that the nature of the visible things is made up of atoms, undividable bodies, molecules and pores... Truly, they who are writing these are weaving a cobweb, putting at the foundation of the sky, of the earth, and of the sea, causes that are so weak and devoid of solidity. Because they did not know to say: 'In the beginning God made the heavens and the earth'. Therefore, the disbelief in God, living in them, cheated them and they said the universe is without governance and without order and is borne randomly ${ }^{131}$.

\section{BIBLIOGRAPHY:}

[1] Andreiu, Anton V. (teacher at Vasile Alecsandri High School of Galați), Credință și științăa. Conferință ținută la Societatea Clerului "Solidaritatea”, Secția Covurlui, în ziua de 24 Februarie 1929, Galați, 1929.

[2] Augustin, Saint, The Literal Meaning of Genesis, transl. by John Hammond Taylor, Ed. Newmann Press, New York, 1982.

[3] Babeș, Victor, Credința și știința. Ședință publică a Ateneului Român dela 4 iunie 1924, București, 1924.

[4] Barbour, I. G., When Science Meets Religion, Ed. Harper Collins, New York, 2000.

\footnotetext{
${ }^{126}$ Collins, The Language of God, p. 229 (Collins, Limbajul lui Dumnezeu, p. 239).

${ }^{127}$ Ionescu, Teologie Ortodoxă și Știință, pp. 175, 184-185.

${ }^{128}$ Ionescu, Teologie Ortodoxă și Știință, p. 176.

${ }^{129}$ Ionescu, Teologie Ortodoxă și Știință, p. 177.

${ }^{130}$ Sfântul Vasile cel Mare, Omilii la Hexaemeron, in idem, Scrieri I, Collection Părinți și Scriitori Bisericești, vol. 17, translation, introduction, indexes and notes by Fr. D. Fecioru, Editura Institutului Biblic și de Misiune al Bisericii Ortodoxe Române, București, 1986, p. 72.

${ }^{131}$ Ibidem, pp. 72-73.
} 
[5] Barrow, J. D. / Tipler, F. J., The Anthropic Cosmological Principle, Oxford University Press, New York, 1986.

[6] Bădulescu, Dan (Pr.), Conflict între “legile” științei și minunile credinței, Editura Agaton, Făgăraș, 2008.

[7] Blomberg, C. L., The Historical Reliability of the Gospels, Ed. Intervasity, Downers Grove, 1987.

[8] Bruce, F. F., The New Testament Documents, Are They Reliable? Eerdmans Publishing Co., Grand Rapids, 2003.

[9] Collins, Francis S., The Language of God: a Scientist Presents Evidence for Belief, Free Press, New York, London, Toronto, Sydney, 2007 (for the translation into Romanian see idem, Limbajul lui Dumnezeu. Un om de știință aduce dovezi în sprijinul credinței, translation from English by Silvia Palade, Editura Curtea Veche, București, 2009).

[10] Costache, Doru (Pr.), "De la conflict și confuzie la complementaritate și dialog. Jean-Pierre Lonchamp, istoria științei și raporturile dintre știință și credință”, in Jean-Pierre Lonchamp, Știință și credință, translation from French by Magda Stavinschi, afterword by Fr. Doru Costache, Col. Noua reprezentare a lumii, XXI: Eonul dogmatic, București, 2003, pp. 163-168.

[11] Darwin, C., The Origin of Species, Ed. Penguin, New York, 1958.

[12] Dobre, Nicolae Vladimir, De la credință la știință și înapoi la credință. Puţină teologie pentru ingineri, dar nu numai pentru ei, Editura de suflet, București, 2011.

[13] Einstein, Albert, Cum văd eu lumea. O antologie, texts selected by M. Flonta, I. Pârvu, translation by M. Flonta, I. Pârvu, D. Stoianovici, notes by M. Flonta, Editura Humanitas, București, $2005^{3}$.

[14] Gould, S. J., "Impeaching a Self-Appointed Judge" (review to Phillip Johnson's book, Darwin on Trial), in Scientific American 267 (1992), pp. 118-121.

[15] Habermas, G. R., The Historical Jesus: Ancient Evidence for the Life of Christ, College Press, New York, 1996.

[16] Habermas, Jürgen / Ratzinger, Joseph, Dialectica secularizării. Despre rațiune și religie, translation by Delia Marga, introduction by Andrei Marga, Editura Biblioteca Apostrof, Cluj-Napoca, 2005.

[17] Haught, John F., Știință și religie de la conflict la dialog, translation from English by Magda Stavinschi, Doina Ionescu, Editura XXI: Eonul dogmatic, București, 2002.

[18] Hawking, Stephen W., "Einstein's Dream", in Visul lui Einstein și alte eseuri, translation from English and foreword by Gheorghe Stratan, Editura Humanitas, București, 2005², pp. 76-90.

[19] Ionescu, Răzvan Andrei (Pr.), Teologie Ortodoxă și Știință: Conflict, Indiferență, Integrare sau Dialog? Care să fie atitudinea noastră față de știință?, Editura Doxologia, Iași, 2015.

[20] Idem, "Repere privind o (încercare de) abordare filocalică a raporturilor dintre teologie și știință", in Tabor VIII/10 (2014), pp. 84-98.

[21] Jastrow, Robert, God and the Astronomers, Ed. W. W. Norton, New York, 1992.

[22] Lewis, C. S., Mere Christianity, Barbour and Company, Westwood, 1952.

[23] Lonchamp, Jean-Pierre, Știință și credință, translation from French by Magda Stavinschi, afterword by Fr. Doru Costache, Col. Noua reprezentare a lumii, XXI: Eonul dogmatic, București, 2003.

[24] Maldamé, Jean-Michel, Christos pentru întreg universul. Pentru o colaborare între știință și credință, Editura Cartimpex, Cluj-Napoca, 1999.

[25] Meyendorff, John (Pr.), Sfântul Grigorie Palama și mistica ortodoxă, translated by Angela Pagu, Editura Enciclopedică, București, 1995.

[26] Miu, Traian-Alexandru, Globalizare și Ortodoxie. Provocări şi perspective, Editura Universitară, București, 2015.

[27] Newman, R. C., "Some Problems for Theistic Evolution", in Perspectives on Science and Christian Faith 55 (2003), pp. 117-128.

[28] Nicolescu, Basarab / Stavinschi, Magda (editors), Știință şi religie. Antagonism sau complementaritate?, Editura XXI: Eonul dogmatic, București, 2002.

[29] Penrose, Roger, Incertitudinile rațiunii (Umbrele minții). În căutarea unei teorii științifice a cunoaşterii, Ed. Tehnică, București, 1999.

[30] Petcu, Lucian-Răzvan (Pr.), Cosmologia creștină și teoriile fizicii moderne, Editura Sophia, București, 2008.

[31] Polkinghorne, J., Belief in God in an Age of Science, Yale University Press, New Haven, 1998.

[32] Pollack, Robert, Credința biologiei și biologia credinței. Ordine, sens și liber-arbitru în științele medicale moderne, translation from English by Viorel Zaicu, Editura Curtea Veche, București, 2007.

[33] Ratzinger, Joseph, Europa în criza culturilor, translation by Delia Marga, introduction by Andrei Marga, Editura Biblioteca Apostrof, Cluj-Napoca, 2008. 
[34] Romanidis, Părintele Ioan, Teologia patristică, translation from Greek, notes, bibliographic completions and afterword by Ion Marian Croitoru, Editura Bibliotheca, Târgoviște, 2012.

[35] Strobel, L., The Case for Christ, Ed. Zondervan, Grand Rapids, 1998.

[36] University of Craiova, Centre for Dialogue between Sciences and Theology, Simpozionul Național "Știință și Teologie - componente complementare ale educației”, first edition, Editura Universitaria, Craiova, 2005; ibidem, second edition, Editura Universitaria, Craiova, 2006.

[37] Vasile cel Mare, Sfântul, Omilii la Hexaemeron, in idem, Scrieri I, Collection Părinți și Scriitori Bisericești, vol. 17, translation, introduction, indexes and notes by Fr. D. Fecioru, Editura Institutului Biblic și de Misiune al Bisericii Ortodoxe Române, București, 1986.

[38] Vitz, Rico (ed.), Intoarcerea spre Răsărit. Filosofi contemporani și credința creștină veche, translation from English by Mihai-Silviu Chirilă, Editura Renașterea, Cluj-Napoca, 2015.

[39] Nikoláou, Mitropolítou Mesogaías kai Lavreotikís, Án ypárchei zoí, thélo na zíso, Ékdosi Ierá Mitrópolis Mesogaías kaí Lavreotikís, Athína, 2013.

[40] Terézi, CH., Grigórios Palamás Methodologiká. I theoría perí «enóseon-diakríseon», Ekdóseis Índiktos, Athínai, 1999.

[41] Chrístou, Panag. K., “I énnoia tís diplís gnóseos katá tón Grigórion Palamán”, in Anátypon ek tís Epistimonikís Epetirídos tís Theologikís Scholís, En Thessaloníki, 1963, pp. 3-12. 